\title{
COMPARATIVE ERROR ANALYSIS IN ENGLISH WRITING BY FIRST, SECOND, AND THIRD YEAR STUDNETS OF ENGLISH DEPARTMENT OF FACULTY OF EDUCATION AT CHAMPASACK UNIVERSITY
}

\author{
Nokthavivanh Sychandone \\ Champasack University Laos \\ Email: Nokdam14@Yahoo.Com
}

\begin{abstract}
This study focuses on comparative error analysis in English writing made by different levels. To investigate the error types, the frequency of error types, the similarities and difference of errors and the last to find the error sources that occur in first, second and third year learners. Error analysis is one type of linguistic study and it focuses on learners' error making. The linguistic category and surface strategy taxonomy are used to find out the types of error. The analysis the phenomenon based on Brown (1980) namely, error identification, error classification, Error description and error explanation. The data from students' writing products, 54 pieces in three levels and the total errors are 571 erroneous sentences. There are two types of errors, namely lexical errors and syntactical errors; eight error categories and twenty-seven error cases. The second year learners made the most error 263 errors or 46, 05\% while first year learners produced 229 errors or 40, 10\% and third year learners made 79 errors or 13, 83\%. There are similarity in errors types, five similar categories and five error cases, but there are three different error categories and eighteen error cases. The main error sources, learners had lack knowledge of English grammatical rule. The overgeneralization (265 errors or 46, 40\%) influences learners' error, language transfer (199 errors or 34, 85\%) still interfere learners' acquisition and simplification (107 errors or 18, 73\%) is one factor that effect learners' errors.
\end{abstract}

Keyword: comparative error, error analysis, lexical error, syntactical error, source error.

\begin{abstract}
ABSTRAK
Penelitian ini difokuskan pada analisis kesalahan komparatif dalam menulis bahasa Inggris yang dibuat oleh tingkat yang berbeda. Untuk menyelidiki jenis kesalahan, frekuensi jenis kesalahan, persamaan dan perbedaan kesalahan dan yang terakhir untuk menemukan sumber kesalahan yang terjadi pada pertama, kedua dan ketiga pelajar tahun. Analisis kesalahan adalah salah satu jenis studi linguistik dan berfokus pada peserta didik membuat kesalahan. Linguistik kategori dan strategi permukaan taksonomi digunakan untuk mengetahui jenis kesalahan. analisis fenomena berdasarkan Brown (1980) yaitu, kesalahan identifikasi, klasifikasi error, kesalahan deskripsi dan penjelasan kesalahan. Data dari produk menulis siswa, 54 buah dalam tiga tingkat dan total kesalahan yang 571 kalimat yang salah. Ada dua jenis kesalahan, kesalahan yaitu leksikal dan kesalahan sintaksis; delapan kategori dan dua puluh tujuh kasus. Peserta didik tahun kedua membuat sebagian besar kesalahan
\end{abstract}


263 kesalahan atau 46, 05\% sedangkan peserta didik tahun pertama diproduksi 229 kesalahan atau 40, 10\% dan pelajar tahun ketiga membuat 79 kesalahan atau 13, 83\%. Ada kesamaan jenis kesalahan, lima kategori yang sama dan lima kasus kesalahan, tetapi ada tiga kategori kesalahan yang berbeda dan delapan belas kasus kesalahan. Sumber kesalahan utama, peserta didik memiliki pengetahuan kurangnya aturan tata bahasa Inggris. The generalisasi yang berlebihan (265 kesalahan atau 46, 40\%) mempengaruhi 'error, transfer bahasa (199 kesalahan atau 34, 85\%) masih mengganggu peserta didik peserta didik akuisisi dan penyederhanaan (107 kesalahan atau 18, 73\%) adalah salah satu faktor yang berpengaruh peserta didik kesalahan.

Kata kunci: kesalahan komparatif, kesalahan analisis, kesalahan yaitu leksikal dan kesalahan sintaksis, kesalahan sumber.

\section{INTRODUCTION}

English language is the first and second or foreign language of some countries. Many countries take English as a compulsory subject in the curriculum. The second learners have many problems about second language learning because there are factors which affect second language learners such as the difference of grammatical rule, different letters, different pronunciation and other. So that second learners make the error, based on James (1998:77) said that an error arises when there was no intention to commit one; it means that learners have not mentioned to make error, but they do not avoid errors then students' error can be classified into linguistic errors. Most second learners make more errors on writing because English writing is formal and organization of writing, concepts of English grammar, so learners face problem in writing.

Error analysis is "the first approach to the study of SLA which includes an internal focuses on learners' creative ability to construct language" (Saville-Troike, 2006:37). It means that is one type of linguist analysis which focused on error learner make. Accordeing to Corder (1982:35) Error analysis is part of psycholinguistic to investigate the language of the second learner and error analysis is a one methodology of psycholinguistic. Ellis \& Barkhuizen (2005:51) described error analysis is "a set of procedures for identifying, describing and explaining learners' errors", Error analysis is like the process of determining the incidence, nature, cause and consequences of unsuccessful in language.

Error is one part of linguistic study because it studies the learners' quality in second language. Saville-Troike (2006:39) said that learners' errors are the windows into the language learners' mind because learners' errors indicate teachers and researchers know about learners' language ability. James (1998:12) furthered that error is "tell the teacher what needs to be taught, tell the researcher how learning proceeds, and a means whereby learner test their hypotheses about the second language". According to Corder (1967:166) errors show that L1 and L2 learners both develop an independent system of language in using, although it is not the adult system nor that of the second language, but it is evidence of a transitional competence.

In studying error, most researchers found out the types of errors to follow on Richards (1977), Duley, Burt and Khrashen (1982) and James (1998) present about descriptive classification of error. That based on kinds of taxonomy into four, namely linguistic category, surface strategy taxonomy, comparative taxonomy and communicative taxonomy.

Linguistic category is error classification that occurs in the English system. James (1998:105)

"carries out errors in terms of where the error is located in the overall system of the based on 
the linguistic item which is affected by the error". It indicates in which component of language the error is located. Language components may include phonology (e.g. pronunciation), syntax and morphology, semantics and lexicon, and style. That error type focuses on the grammatical rule and vocabulary usage.

Surface strategy taxonomy is type of error that describes the errors appear on the omission, addition, misformation, misordering some items in the sentences. According to James (1998:106) states that surface strategy taxonomy is based on the he ways in which the learner's erroneous version is different from the presumed target version. The surface strategy taxonomy is the English system about omit some items, add some items that is unnecessary or incorrect, misformation uses the wrong form of structure or morpheme (run-runned, that replace those, her refers his) and the last misordering is incorrect arrangement of the sentences (what dad is doing?; he is a men tall).

According to Selinker's theory (Fauziati, 2009:169) describe the interlangugae system has a cognitive emphasis and a focus on the strategies that learners employ when leaning a second language. The learners' errors are the product of the cognitive process, so that the researcher followed Selingker's theory based on interlanguage system. He suggests that there are five processes central in leaning second language such as overgeneralization, transfer or training, strategies of second language learning, strategies of second language communication and language transfer.

There are some previous studies that investigated the error on students' writing and researchers used other theories to find the error types on writing such as Zheng and Park's work (2013), they investigated the error on English writing made by Chinese and Korean university students. They found out error types by using surface strategy, thus it showed that most of learners made more error on omission some item (article, plural noun $-\mathrm{s}$, preposition) and addition some unnecessary item (article, preposition, verb). The character of error related with English grammar especially part of speech and English form.

As like as Bootchuy's work (2008) found 165 errors on students' writing and she followed Richard (1971) to classification namely: interference error, intralingual errors and development errors. There were three high error types such as omission (subject, verb and other) is $37,57 \%$, incorrect form of compound is $23,03 \%$ and word-order is $9,07 \%$. The types of errors show the character of error that learners make wrong on their sentences and bring to the error source. But this research is different because researcher used more than one theory to find the type of errors.

However, this research is similar with other previous studies that based on error types on writing, but there are different something such as the research place, method to find error classification, the different theory and strategy of analysis. Moreover, this research shows the similarities and difference of errors types that is different from other, that is different from other previous study. They found only the error types and the errors source, but they did not compare how difference of error in different levels. This research is the first in Champasack University to study on students' error because most of researchers focused on test the material in second language.

Second learners are in Laos who learn English as the foreign language and specific in English department of Champasack University, who learned on English major. Through researcher's experience in English teaching there for five years then she saw that most second learners are not successful in English writing because they made some errors and they are not good in English writing. So that the researcher would like to know the types of errors and she focuses on "comparative error analysis in English writing by First, Second and Third year students of English department at Champasack University". 
The researcher took two theories to find out the types of errors because they are appropriate to investigate the error on the writing, there are linguistic category and surface strategy taxonomy and error source based on cognitive process central. This research is significant for improving English writing especially teachers will know the weakness of learners and they will improve their teaching strategy. Students get more benefit on this research because they know the error types and their weakness on writing, thus it stimulus to students to practice more in writing. The last, for the other researchers who are interested in writing errors, it is the one guideline to find errors and it is the deviance to support their researches.

This current study focuses on four objectives that are interesting to find out. First, researcher would identify the weather of errors types are made by three levels. Second point, she would deep to the frequencies of each types of error are made by three level. Third point, it investigates the similarities and differences of type of errors of learner on writing in First, Second and Third years. The last point, it finds out the error sources that occurs on students' writing in First, Second, and Third year of English Department.

\section{RESEARCH METHOD}

According to Fraenkel, et.al (2012:425) qualitative research is the famous method to be used in variety fields; these include comparison between alternative methods of teaching. According to Moleong (Bogdan and Taylor, 2004: 36) qualitative research is research procedure that results in descriptive data namely written and speech form people act and the attitude that real action. Sometimes learners describe about their experience even or routine activities. So that, there are no data from the numerals data and not use mathematic procedure, the researcher uses qualitative for correcting data to seek the error on the students writing. The nature of the data comes from varied erroneous sentences (quality problem). The qualitative research emphasizes on inductive analysis and places where data as the bases of the discussion to know the problem.

The subject of research is students of first, second and third year of English Department at Champasack University academic year of 2015/2016. There are 14 students in first year, 20 students in second year, and 20 students in Third year.

The object of the study is type of errors on students' written form sentences containing errors are taken from different level of students' composition in (written production) of English Department at Champasack University academic year 2015/2016.

I used the elicitation technique to find out data because elicitation is technique to lure students to produce the writing and give instruction to writing composition. The procedure of collecting data, researcher got the data of the students' English writing from one source: the writing task. The advantage of collecting data by asking the research participants to do a writing task is obtaining highly authentic data, but they would write in a controlled environment (giving the topic) in the same topics but it conducted in different levels, sitting in a classroom. The researcher collected data one times and distance of time is one week and one time.

In analyzing data, there are two techniques namely, the procedures of error analysis and the frequency of error type. The procedures of errors analysis suggested by Brown (1980), namely: error identification, error classification, error description and error explanation. The frequency of error types, it based on Hatch and Lazaraton to find out the frequencies of error types by percentage. They provided the formula. 


\section{RESEARCH FINDING AND DISCUSSION}

This research found out the erroneous on the sentences based on linguistic category and surface strategy taxonomy. Researcher found the total of error about 571 erroneous sentences and it divided into groups, namely lexical errors are about 131 errors and syntactical errors are around 440 errors.

\section{The Types of Errors made by First, Second and Third Year Students}

The first year Students were new freshmen and they had less experience in English language, so they produced errors on their sentences. The researcher found total number of errors about 229 errors or $40,10 \%$ that made by first year learners that include from lexical errors are 45 erroneous sentences or 7, 88\% and syntactical errors are 184 erroneous sentences or $32,22 \%$. The second year students made the total 263 errors or $46.05 \%$ that consists of lexical errors are 62 erroneous sentences or $10,87 \%$ and syntactical errors are 201 erroneous sentences or $35,20 \%$. The third year, the errors total is 79 erroneous sentences or $13,83 \%$ that concludes lexical errors 24 errors or $4,20 \%$ and syntactical error 55 errors or $9,63 \%$.

\section{Lexical Error}

Lexical error is the process of converting a sequence of characters into a sequence of token means or we can say that lexical error is making the wrong choice of word for the stylistic context. The word is roughly correct, but wrong I "flavor" then choosing wrong words to complete the sentence and wrong level of formality.

\section{Wrong Spelling Words}

Spelling is the process or activity of writing word and naming the letter and the way in which a word is spelled. Spelling is the act of forming of words letter and the way how to make a word is correctly spelled. Thus some learners made wrong spelling words because the different of the character of native letters and English letters

Example: Nixt, I went to take a shower at 8:30 pm

One example illustrates that learners made error on lexical error because they did not recognize English word, so they produced erroneous word. This sentence shows that error occurs in spelling word "next" but learner wrote "nixt" which is wrong form and no meaning then the correct is "next, I went to take a shower at 8:30".

\section{Wrong Selection Words}

Wrong selection word is the process of choosing the wrong word to complete sentence, learners choose other word instead of the correct word such as learner mentions to write "part" but they write "park", they want to write "nine o'clock" but they write "night o'clock" and they use wrong example "I look for any lesson" the word "any" is used in interrogative and question sentence but learners used in position sentence.

\section{Example: I cleaned my bad}

This sentence indicates that learner chose the wrong words because the characters of letters are similar but different a litter bit. Learner mentions to write "bed" but he/she wrote "bad", so this sentence is incorrect then the correct sentence is "I clean my bed" 


\section{False Friend}

"False friend" are words that have seemed to be the same but in fact, there are different meanings and it is often confused with the words in another language with a different meaning because the two words look or sound similar.

Example: I thing that if I can teach in my hometown

This sentence shows the similar of English words that makes student to be confused. This case is similar pronunciation "think" and "thing" the correct sentence is "I think that if I can teach in hometown".

\section{Syntactical Errors}

Syntax is the structure of language or grammar; syntax consists of tenses, subject, verb, preposition, conjunction and other words to make sentences, so that syntax is the knowledge about grammar and description of word classes, sometimes these were called part of speech, and how to numbers of these classes go together to phrase form and sentences.

This research, writer found syntactical errors in three levels students of English Department at Champasack University and it include in five categories such as: (1) Verb "to be", (2) Verb, (3) Preposition, (4) Conjunction, (5) Sentence construction.

\section{Verb "to be"}

Verb "to be" is said to the most important of English language, constantly changing form, sometimes without much of a discernible pattern, considering that we use it so often, it is really too bad for "to be" has to be most irregular, slippery verb in the language.

Example: We are have lunch at 11:30

From example above shows that learner has lack grammatical knowledge and she/he misunderstood about simple structure, so learner puts verb "to be" in the sentence to describe activities then correct sentence is "we have lunch at 11:30".

Verb

Verb is one part of speech and sentences because all sentences structure can't miss verb. Verb mortifies subject that makes people to understand the meaning of the speaker. Verb is part of tenses or one composition of sentences, verb predicate by using such as present simple "I drink water" and past simple "I drank water" using verb in the present simple is like infinitive verb when we use verb in past simple verb character of letter.

Example: I watching TV.

The sentence above shows that learner did not remind the English structure then she/ he created new form is "I watching TV" learner put -ing in the infinitive verb (V1) that is unnecessary and incorrect form, so that the correct is "I watch TV" because the learner can't remind English grammatical structure then she/he creates new form as similar as English form.

\section{Preposition}

Preposition is one the composition of the sentences and part of speech, it used to combine between word to word and that make that sentence is meaningful and correct with English 
grammar. Preposition is the word which is used to show and describe the places where something is location.

Example: My family still lives in there

The sentence above shows that learner made error on addition unnecessary preposition because learners do not remember the preposition rule then they made error. The first error sentences is "My family still lives in there" the rule of using "there" does not put preposition because "there" is mean the place and it is full meaning in itself, the correct sentence is "My family still lives there".

\section{Conjunction}

Conjunction or connection idea is the part of speech that is important one because conjunction words combine between word to word, sentences to other sentences and it includes on clause. Especially English writing conjunction is one composition that makes writing text is perfect in context.

Example: I had party $\ldots$ and drink beer together.

From one example indicates that learner ignored English rule when she/he wants to combine the two clauses together such as the first error sentence is "I had big party _ drink beer together" there are two clauses between word "party" and "drink", maybe learner refer to spoken language and wrote the sentence, so the correct is "I had big part and drink beer together".

\section{Sentence Construction}

Sentence construction describes some items in sentences and word phrases; it is the grammatical arrangement of words in sentences. The error happened in this case because organization of structure is incorrect with English grammar. Moreover, Sentence construction describes construction of sentences some item in sentences and word phrase; it is the grammatical arrangement of words in sentences.

Example: Before __ go to take a shower at seven o'clock

Three examples are omission subject case, the sentence is "before go to take a shower at seven o'clock" is similar as case in the first because learner ignore the English grammar, he/ she followed spoken language and wrote the sentence. The correct sentence is "before I go to take a shower at seven o'clock".

\section{The Frequency of Error Types made by First, Second and Third Year Students}

In the first year learners produced 229 errors or $40,10 \%$. There are two error types and seven categories. Lexical errors are 45 error or 7, 88\%, it consists of three categories namely wrong spelling word (23 errors or 4, 02\%); wrong selection words ( 15 errors or $2,62 \%$ ) and false friend ( 7 errors or 1, 22\%). While syntactical errors are 184 errors or $32,22 \%$ and it consists of four categories such as Verb (109 errors or 19, 08\%), preposition (35 errors or 6, $12 \%$ ); Conjunction (21 error or 3, 67\%) and sentence construction (19 errors or 3, 32\%)

The second year learners made more errors than first and third year because they do not understand the topic to writing then they used other tenses in their paragraph. The errors total 
is 263 erroneous sentence or $46,05 \%$. Lexical errors are 62 errors or $10,87 \%$ and it has two categories namely wrong spelling words ( 55 errors or 9,63 ); wrong selection words ( 7 errors or $1,22 \%$ ) while syntactical errors (201 errors or 35, 20\%) is more erroneous sentences because learners had lack of English grammar. There are five categories such as Verb "to be" (6 errors or $1,05 \%)$; verb (107 errors or $18,73 \%$ ); preposition (38 errors or $6,65 \%)$; conjunction (17 errors or $2,97 \%$ ) and sentence construction (33 errors or $5,77 \%$ ).

Third year learners made some of errors because they have more experience and understand the English grammar more than first and second year. learners made 79 errors or $13,83 \%$, then Lexical errors is 22 erroneous sentences or 4, 20\% that consist of two categories namely wrong spelling words (20 errors or 3, 50\%) and wrong selection words (4 errors or $0,70 \%$ ). Syntactical errors are 55 errors and it has four categories such as verb "to be" (3 errors or 0 , $52 \%$ ); verbs ( 24 errors or $4,20 \%$ ); preposition (15 errors or 2, 62\%) and sentence construction (13 errors or $2,27 \%$ ), but it is found errors that relates in conjunction.

In the two types of errors indicate that most of learners made more errors on syntactical errors especially about "verb", it means learners have lack English grammar and they do not use tenses in the appropriate situation. Moreover, they created the new form that is similar in the English grammar but it is incorrect. Lexical errors are the one problem for learners' English writing because they have not reminded some spelling words because the different of letters of their mother language.

Table 1. the types of Error made by First, Second and Third Year Students

\begin{tabular}{|c|c|c|c|c|c|c|c|}
\hline & \multirow{2}{*}{$\begin{array}{c}\text { The kinds of Error } \\
\text { categories }\end{array}$} & \multicolumn{2}{|c|}{ First year } & \multicolumn{2}{|c|}{ Second year } & \multicolumn{2}{|c|}{ Third year } \\
\hline & & Number & $\%$ & Number & $\%$ & Number & $\%$ \\
\hline \multirow[t]{4}{*}{ A } & Lexical Error & 45 & $7,88 \%$ & 62 & $10,87 \%$ & 24 & $4,20 \%$ \\
\hline & Wrong spelling of words & 23 & $4,02 \%$ & 55 & $9,63 \%$ & 20 & $3,50 \%$ \\
\hline & Wrong selection wrong & 15 & $2,62 \%$ & 7 & $1,22 \%$ & 4 & $0,70 \%$ \\
\hline & False Friend Words & 7 & $1,22 \%$ & - & - & - & - \\
\hline \multirow[t]{6}{*}{ B } & Syntactical Error & 184 & $32,22 \%$ & 201 & $35,20 \%$ & 55 & $9,64 \%$ \\
\hline & To be & - & - & 6 & $1,05 \%$ & 3 & $0,52 \%$ \\
\hline & Verb Tenses & 109 & $19,08 \%$ & 107 & $18,73 \%$ & 24 & $4,20 \%$ \\
\hline & Preposition & 35 & $6,12 \%$ & 38 & $6,65 \%$ & 15 & $2,62 \%$ \\
\hline & Conjunction & 21 & $3,67 \%$ & 17 & $2,97 \%$ & - & - \\
\hline & Sentences construction & 19 & $3,32 \%$ & 33 & $5,77 \%$ & 13 & $2,27 \%$ \\
\hline \multicolumn{2}{|r|}{ Total } & 229 & $40,10 \%$ & 263 & $46,05 \%$ & 79 & $13,83 \%$ \\
\hline
\end{tabular}

The table shows that the types of error in the three levels with the number of error types and percentages are similar in error types, but they are different in the number of error and different of error categories. There are two error types, namely lexical errors and syntactical errors. Lexical errors have three categories such as wrong spelling words wrong selection words and false friends while syntactical errors have five such as verb to be, verb tenses, preposition, conjunction and sentence construction. The second year learners made more errors than first and third years.

\section{The Similarities and Differences of Error Types made by First, Second and Third Year Students}

After the researcher analyzed data, she found the similar and different error types in three levels. They are important because it shows that the types of errors which learners made 
difference from the others. The error types are similar in three levels but they are different in categories and error cases.

In the categories have eight characteristics namely wrong spelling words, wrong selection words, false friend, verb "to be", verb tenses, preposition, conjunction, and sentence construction. Some of categories divided the some cases such as verb "to be" (addition unnecessary verb "to be"); verb has 12 cases, preposition has 3 cases, conjunction has 3 cases and sentences construction has 3 cases.

\section{The Similarities of Error Categories and Error Cases}

In three levels made the similarities of error categories that have five error characteristic such as wrong spelling words, wrong selection words, verb, preposition, and sentence conjunction.

Similarities of error cases have five cases that three levels learners made errors in the same cases such as addition unnecessary verb, wrong selection verb, addition preposition, wrong selection preposition, omission subject.

\section{Difference of Error Categories and Error Cases}

The table above shows that there are some similarities and difference of errors which three year learners made, so that there are three thing that are different such as the different number of error (table: 1) that happen in three years, the difference of categories and difference of cases.

There are few different categories that appear in the three years and they are different from other year. There are 3 categories that some learners made on different categories namely: false friend is found only the first year learner made this category, as like as verb "to be" found in second and third year, but first learner did not made error on this category. And last conjunction did not find in the third year because learners do not made errors on this category.

Other error cases that learners made are different in each year, thus there are 19 cases namely: false friend, addition unnecessary verb "to be", omission verb, omission of preparatory "to" after certain verb, using past simple instead present simple, using present continue instead present simple, using future simple instead of present simple, using had $+\mathrm{V} 1$ instead of present simple, using had to $+\mathrm{V} 1$ refers to present simple, using have $+\mathrm{V} 1$ instead of present simple, using to $+\mathrm{V} 1$ instead of present simple, addition $\mathrm{V}+\mathrm{ing}$ refers present simple, addition $\mathrm{V}+\mathrm{ing}$ after preparatory "to", omission preposition, omission conjunction, addition conjunction, wrong selection conjunction, addition article, using objective pronoun replace subjective pronoun.

The difference of error cases show the weakness of learners in each year there are different and those errors being to error sources. Most of the error characteristic related with the syntax or English grammar about tenses usage and part of speech usage that some learners can't remind or recognize the English grammatical rule. Sometimes learners will transfer native language structure into target language then these sentences are errors, one more error some learners made more error on vocabulary or words because the different of letter character then they can't remember the spelling words, so that is the cause of errors.

Table 2. the Similarities and Difference of Error Categories and Error Cases

\begin{tabular}{clccc}
\hline No & Types of Error & First year & $\begin{array}{c}\text { Second } \\
\text { year }\end{array}$ & $\begin{array}{c}\text { Third } \\
\text { year }\end{array}$ \\
\hline 1 & Wrong word spelling & $\checkmark$ & $\checkmark$ & $\checkmark$ \\
2 & Wrong selection word & $\checkmark$ & $\checkmark$ & $\checkmark$ \\
3 & False Friend Words & $\checkmark$ & - & -
\end{tabular}


Verb to be

a. Addition unnecessary verb to be

Verb

Omission verb

Omission of preparatory "to" after certain verb

Addition unnecessary verb

Wrong selection verb

Using past simple instead present simple

Using present continue instead present simple

Using future simple instead of present simple

Using Had +V1 instead of present simple

Using had to $+\mathrm{V} 1$ refers to present simple

Using have $+\mathrm{V} 1$ instead of present simple

Using to + V1 instead of present simple

Addition Ving refers present simple

Addition -ing with V after "to"

6 Preposition

Omission preposition

Addition preposition

Wrong selection preposition

7 Conjunction

Omission conjunction

Addition conjunction

Wrong selection conjunction

8 Sentences construction

Addition article

Omission subject

Using objective pronoun replace subjective pronoun

\section{The Error sources made by First, Second and Third Year Students.}

According to Selinker's theory based on cognitive central process, there are described into five cause errors when researcher analyzed then it found only two error source and one error source is new error source, thus there are three main error sources namely overgeneralization, simplification and language transfer.

\section{Overgeneralization}

This case, some of rules of interlangauge system maybe the result of overgeneralization of specific rules and feature of the target language that means foreign learners ignore the English form that is not correct with English form, and then they make error by new form. This cause of error occurred when the learners have mastered a general rule but they do not know the concentrations to that rule because learners' cognitive process to comprehend in English grammar. 


\section{Simplification}

Simplification occurs when second learners absent words in the sentence, second learners omit some item to complete sentences then it is made those sentences are not correct. According to Duley, Burt and Kachen (1982:155) "Omission of content word, although typical in the early stages of L1 acquisition, is not common in sequential L2 acquisition where the learners is older and more cognitively mature" This cause occurs on sentences because learners do not remind the English structure or the cognitive process then they do not write necessary item in sentence and sometimes learners forget rule of sentence structure, then their sentences are incorrect with English grammar.

\section{Language transfer}

Language transfer is some of the rule of interlanguage and the result of transfer from learners' first language form to target language. Sometimes it is called that influence of first language; it is described different theoretical accounts of the role of learners' first language in learning second language or foreign language. Transfer language occurs when learners do not remember the English grammatical rule then they transfer native language structure into target language or some learners transfer the vocabulary. There are two major of language transfer such as: positive transfer and negative transfer. Positive transfer occur on sentences when the first language structure is used in second language form that is appropriate or correct in second language. The negative transfer is different structure between first language form and second language form then result in error.

Table 3. The Error Sources of First, Second and Third year learners

\begin{tabular}{cccccccc}
\hline \multirow{2}{*}{ No } & \multirow{2}{*}{ The Error sources } & \multicolumn{2}{c}{ First Year } & \multicolumn{2}{c}{ Second Year } & \multicolumn{2}{c}{ Third Year } \\
\cline { 3 - 8 } & & Number & $\mathbf{\%}$ & Number & $\mathbf{\%}$ & Number & $\%$ \\
\hline 1 & Overgeneralization & 105 & $45,85 \%$ & 123 & $46,76 \%$ & 37 & $46,83 \%$ \\
2 & Simplification & 50 & $21,83 \%$ & 47 & $17,87 \%$ & 10 & $12,65 \%$ \\
3 & Language Transfer & 74 & $32,31 \%$ & 93 & $35,36 \%$ & 32 & $40,50 \%$ \\
\hline & Total & 229 & $100 \%$ & 263 & $100 \%$ & 79 & $100 \%$
\end{tabular}

The table shows that most of learners made more overgeneralization; it means that learners have lack of grammatical rule in the target language. Especially the second year, learners made error on the overgeneralization 123 errors or $46,76 \%$ because they created new form and used the wrong tenses in the situation. They do not remind the English form then they made the errors on the sentences.

The second error source, language transfer influences the second language learners because some learners transfer native language (form and Lao language transcript) into English language. Second year learner made more errors on language transfer because they transferred their native language structure to target language about 93 errors or 35, 36\%.Sometimes learners did not use English form but they transfer to Lao form because sometimes Lao form is different from English form, so they made errors.

The last simplification is the new error source that does not have in the Selinker's theory in cognitive processes center. In this the case, learners omit some item or morpheme in the sentence and those items are necessary to complete the sentence. The first year learners made more errors (50 errors or 21, 83\%) that second and the third year. Some learners did not understand the English grammatical rule, so they omitted some items on sentences. 


\section{CONCLUSION}

After researcher found the error on students' writing in different levels (first, second and third years), there are 54 participates and 54 pieces from learners' writing products. Next she followed the linguistic category and surface strategy taxonomy to find the error and identification of error types, thus she found the total 571 errors and there are two types of errors, namely lexical errors and syntactical errors. In the lexical errors are 131 erroneous sentences or 22, $94 \%$ and syntactical errors are 440 erroneous sentences or $77,05 \%$.

The lexical errors consist of three categories such as wrong spelling words (98 errors or $17,16 \%$ ); wrong selection words ( 26 errors or $4,55 \%$ ) and the last false friends ( 7 errors or 1 , $22 \%)$.

The Syntactical errors have five categories, namely verb to be ( 9 erroneous sentence or $1,57 \%$ ), verb tenses (240 erroneous sentence or $42,03 \%$ ), preposition ( 88 error or $15,41 \%$ ), conjunction (38 errors or $6,65 \%)$ and sentence construction (65 erroneous sentences or 11 , $38 \%)$.

The second year learners made more errors than first and third year learners; there are 263 erroneous sentences, but second year learners produce 229 erroneous sentences and third year learners made 79 error sentences.

There are similarities of error types, namely lexical errors and syntactical errors then there are five similar error categories and five error cases. On the other hand, there are three different error categories and eighteen different error cases.

The Error sources have three factors, namely overgeneralization occur on the writing because learners do not remind the English structure then they create the new form that look similar in English form. Second factor is simplification that appears on learners' sentences when they add more unnecessary item or omit some item (verb, preposition, conjunction, subject and article). The last factor is language transfer, most learners transfer their native language structure into target language and sometimes they use native spoken language in English writing that is cause of errors.

\section{REFERENCES}

Bootchuy, Tiptida. (2008) An analysis of error in academic English writing by a group of First-year Thai graduates majoring in English. (Master's Thesis) Kasetsart Unversity, Thailand.

Brown. H. Douglass (1980) Principles of Language Learning and Teaching. New Jersy: Practice Hall.

Corder, S. Pit (1982) Error Analysis and Interlanguage. Oxford University Press

Corder, S. Pit (1967) The Significance of Learners' Errors. International Review of Applied Linguistics in Language Teaching (IRAL),5(4), 161-170. http://dx.doi.org/10.1515/ iral.1967.5.1-4.161

Dulay, Heidi; Marina Burt and Stephen Krashen (1982) Language Two. New York: Oxford University Press.

James, Carl (1998) Error in Language Learning and Use: Exploring Error Analysis. London: Routledge 
Ellis, Rod \& Gary, Barkhuizen (2005) Analysing Learner Language. Oxford University Press. UK.

Fauziati, Endang (2009) Reading on Applied Linguistics. Surakarta: Muhammadiyah University Press.

Fraenkel, R. Wallen, E. Hyun, H. (2012) How to Design and Evaluate Research in Education. McGrraw-Hill.

Moleong (1985) Metodologi Peneliatan Kualitatif. Bangdung PT Remaja Rasa Karya.

Rechard, J. (1977) Error Analysis: Perspective on Second Language Acquisition. London: Longman.

Saville-Troike, Muriel (2006) Introducing Second Language Acquisition. Cambridge: C.U.P

Zheng, Cui \& Park, Tea-Ja. (2013) An Analysis of error in English Writing made by Chinese and Korean University students. Theory and Practice in Language Studies. 2013 ACADEMY PUBLISHER Manufactured in Finland, Vol.3, No.8, pp. 132-1351, August 2013. 